\title{
As abordagens teóricas da competição interjurisdicional e os percalcosos analíticos da dinâmica federativa: por uma perspectiva totalizante
}

\author{
Renato Luis Pinto Miranda* \\ Heriberto Cairo Carou ${ }^{* *}$ \\ Rosa de la Fuente Fernández $z^{* * *}$
}

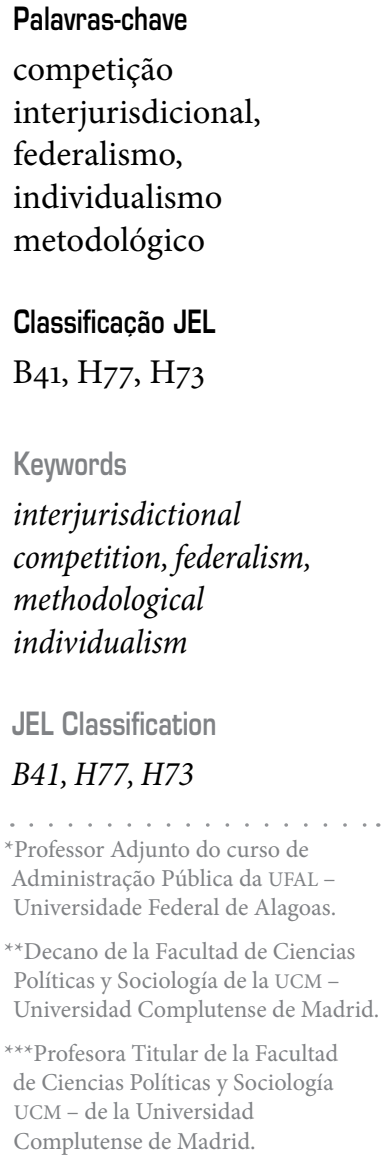

\section{Resumo}

O presente trabalho se dedica a investigar os pressupostos analíticos utilizados pelas teorias hegemônicas da economia do setor público (a Welfare Economics, a Public Choice Theory e a New Institutional Economics) no estudo da competição interjurisdicional, identificando suas limitações e sugerindo, posteriormente, uma nova forma de concepção desse objeto, mediante sua abordagem histórico-concreta. A dinâmica federativa é concebida por essas teorias hegemônicas como produto de um "jogo", composto de agentes racionais maximizadores, desconsiderando-se a influência exercida pelas macroestruturas sociais na composição dos seus movimentos. Em face disso, propõe-se aqui a abordagem dos contornos assumidos pelo arranjo federativo com base nas contradições expressas na própria materialidade institucional, concebendo-o enquanto fenômeno constitutivamente interdependente à conformação das matrizes espaço-temporais do padrão de acumulação.

\section{Abstract}

The following research investigates the analytical assumptions used in the hegemonic theories of the economy of the public sector (Welfare Economics, Public Choice Theory and New Institutional Economics) in the study of interjurisdictional competition, by identifying its limitations. It suggests, subsequently, a new conceptual form of the subject using a historical-concrete approach. The federative dynamic is conceived from this hegemonic theories as the product of a "game", composed of maximizing rational agents. It disregards, however, the influence exerted by social macrostructures in the composition of its movements. In light of this, the approach to the outlines assumed by the federative arrangement, from the contradictions expressed in its own institutional existence, is proposed here, while conceiving this as a constitutionally interdependent phenomenon to the conformance of the of space-time matrices of the standard of accumulation. 


\section{1_Introdução}

Uma das temáticas mais relevantes no âmbito dos estudos sobre o federalismo é a questão da competição interjurisdicional, concebida enquanto uma disputa travada entre os entes - em regra, subnacionais - em torno de diferentes fatores, como, por exemplo, o fornecimento de bens públicos, a arrecadação de receitas tributárias, ou até, a atração de investimentos privados para os seus respectivos territórios. ${ }^{1}$ As principais abordagens dedicadas a esse fenômeno o ilustram como um jogo, cujas regras são estabelecidas conforme variam os parâmetros de "eficiência" e de "competitividade", fundados na suposição de uma racionalidade instrumental, considerada universal a todos os atores envolvidos.

Por outra perspectiva, os diversos formatos assumidos pelo federalismo nos diferentes contextos históricos o revelam enquanto um fenômeno multidimensional, cuja essência vai além de uma mera forma de organização territorial, ou ainda, de um simples mecanismo de descentralização administrativa. As questões federativas - tomadas como fração de uma totalidade concreta - caracterizam-se por congregarem interesses de distintas ordens, seja políticos, seja econômicos, seja regionais. Assim, o arranjo federativo manifesta-se como um objeto complexo, composto pelo movimento das suas contradições em processo, as quais materializam a coexistência de elementos como: a unidade e a diversidade, o poder geral e o poder local, e a união e a autonomia dos entes federativos.

A competição interjurisdicional é estudada, principalmente, valendo-se das teorias hegemônicas da economia do setor público (a Welfare Economics, a Public Choice Theory e a New Institutional Economics), as quais, por sua vez - embora apresentem distinções fundamentais no curso da sua superveniência-, fincam seus pressupostos analíticos nos parâmetros estabelecidos pelo individualismo metodológico, ${ }^{2}$ norteando a investigação dos fenômenos pela perse- guição dos seus microfundamentos. Nesse esteio, os entes federativos são concebidos, em regra, na qualidade de “jogadores", atuando de forma isolada, em busca da maximização dos próprios interesses. Essa perspectiva concebe a dinâmica de funcionamento do objeto como mero agregado de racionalidades individuais, negligenciando tratar-se o arranjo federativo de uma expressão da materialidade institucional do Estado capitalista, a qual se constitui em condicionamento recíproco com o padrão de acumulação historicamente determinado.

Diante disso, tendo em vista a estruturação dos esquemas analíticos constantes nessas teorias, assim como a própria complexidade da dinâmica federativa, o presente trabalho busca investigar: a) quais pressupostos subsidiam a análise da competição interjurisdicional por tais correntes e; b) qual outra abordagem pode ser utilizada na percepção desse fenômeno. Assim sendo, tem-se, então, por objetivos, a identificação dos pressupostos analíticos utilizados pelas ditas escolas, identificando-se, criticamente, as suas limitações e, posteriormente, a sugestão de um horizonte de investigação, capaz de oferecer uma abordagem histórico-concreta desse objeto. Tendo por base esses objetivos, o presente trabalho se divide em duas partes: a primeira, dedicada a percorrer, criticamente, as teorias hegemônicas da economia do setor público, em abordagem dos fundamentos básicos de racionalidade que a sustentam e; a segunda, consubstanciada na apresentação de uma perspectiva inclinada à compreensão do arranjo federativo a partir das contradições expressas na própria materialidade institucional, tomando-o enquanto fenômeno reciprocamente condicionado pelas matrizes espaço-temporais do padrão de acumulação. 


\section{2_Os pressupostos das teorias hegemônicas na análise federativa da competição interjurisdicional}

O presente tópico dedica-se à investigação dos fundamentos sobre os quais se assentam os pressupostos de análise da dinâmica federativa, utilizados pelas teorias hegemônicas da economia do setor público - a Welfare Economics, a Public Choice Theory e a New Institutional Economics -, em particular, no que se refere à competição interjurisdicional entre os entes federativos subnacionais. Com esse propósito, faz-se, aqui, uma abordagem crítica das referidas escolas de pensamento, percorrendo os postulados de racionalidade básicos que as alicerçam e identificando as limitações inerentes aos seus esquemas analíticos. Como forma de evidenciar a efetiva determinação histórica dessas teorias, elas serão abordadas segundo o contexto do seu surgimento, demonstrando-se, dessa forma, o condicionamento recíproco entre a sua proeminência e as transformações ocorridas no capitalismo contemporâneo. Esse modo de exposição põe-se a desqualificar eventuais suposições sobre a metamorfose meramente intelectual de tais teorias, traçando, para tanto, um percurso que vai desde a ascensão histórica do modelo intervencionista de Estado até o cenário de competitividade global, no qual se encontram os Estados contemporâneos.

A Crise de 1929 trouxe à tona as principais incongruências do liberalismo econômico, razão pela qual, acompanhado da emergência do keynesianismo, ensejou-se o chamado "Estado de Bem-Estar". Os contornos desse modelo de Estado foram traçados no desenrolar da reestruturação econômica e política do pós-guerra, que culminou na teoria econômica denominada Welfare Economics, caracterizada pela tentativa de conciliação entre o keynesianismo e os fundamentos teóricos da economia neoclássica ("síntese neoclássica"). ${ }^{3} \mathrm{O}$ Estado intervencionista era responsável, portanto, pela cor- reção das "falhas de mercado" e pelo provimento dos bens públicos, além de facilitar a consecução das transações comerciais e corrigir externalidades. Esse posicionamento do Estado colocava-o na inevitável condição de ente exógeno à economia e à sociedade e ainda fazia com que esse se visse imbuído de, externamente, otimizar ${ }^{4} \mathrm{o}$ bem-estar econômico global, mediante a condução do somatório das utilidades individuais (Affonso, 2003).

A pressuposição do Estado como guardião do interesse público, maximizador do bem-estar social, tornou-se muito presente da denominada "primeira geração" das teorias sobre o federalismo, difundidas, principalmente, no decorrer das décadas de 1950 e 1960. Paul Samuelson, Richard Musgrave e Kenneth Arrow são considerados os principais expoentes dessa escola: o primeiro, dedicado à investigação da natureza dos bens públicos; o segundo, a uma perspectiva normativa do federalismo, considerando-o enquanto uma articulação de subdivisões voltadas para o alcance de maior eficiência das funções fiscais de correção das "falhas de mercado" (alocação, distribuição e estabilização); e o terceiro, por sua vez, estudioso dos papéis dos setores público e privado, questionador dos fundamentos da ação descentralizada do Estado. ${ }^{5}$ As teorias da primeira geração difundidas por esses teóricos tinham em comum a atribuição de um papel importante ao governo central, que, dentro dos parâmetros de bem-estar então estabelecidos, deveria se ocupar de uma distribuição equitativa da renda, de modo a manter a economia em níveis elevados de estabilidade e de preço (Oates, 2005).

Embora a Welfare Economics não tenha dedicado muita atenção ao nível intermediário de governo, pode-se dizer que se caracterizava pela difusão de um federalismo cooperativo, articulado pelo governo central, que fazia uso do sistema federativo como uma ferramenta exógena de pro- 
moção da eficiência na alocação de recursos e provisão de bens públicos (Oates, 1990). As discussões tidas como mais relevantes no curso da Welfare Economics foram aquelas travadas acerca da noção de centralização/descentralização, sendo questionado, entre outros aspectos, as dificuldades de atendimento às preferências regionais no fornecimento eficiente dos bens públicos, concomitantemente ao ganho de escala proporcionado pela oferta centralizada de tais bens. ${ }^{6}$

Diante desse questionamento, surge uma das mais conhecidas teorias acerca da competição interjurisdicional, qual seja, o difundido "modelo de Tiebout", expresso no seu artigo "A pure theory of local expenditure", o qual, embora tenha sido publicado em 1956, veio a ganhar ampla difusão apenas com a proeminência da Public Choice Theory nas análises da dinâmica federativa. Tiebout considera como ponto-chave de sua teoria a ação individual, concebendo os agentes como consumidores-eleitores, dotados do poder de decisão sobre em qual território residir, conforme a compatibilidade das suas preferências com os bens públicos e os serviços oferecidos pelos governos de cada localidade. Para esse autor, os indivíduos têm o pleno conhecimento das receitas e das despesas dos pacotes oferecidos pelos governos, podendo escolher entre um grande número de comunidades, com total mobilidade para transitar e viver em cada uma delas. Por essa ótica, cada jurisdição se comporta enquanto um agente privado, maximizador do seu autointeresse, consubstanciado, nesse caso, na atração de indivíduos para o seu território (Kenyon, 1997).

Além de as jurisdições terem interesse na atração de cidadãos consumidores para aumentarem a sua receita tributária, Wilson (1999) aponta o fato de os governos locais serem controlados por proprietários, os quais buscam maximizar o valor dos seus negócios, assim como o emprego das receitas tributárias no fornecimento dos bens e dos ser- viços públicos.7 Segundo os estudiosos da Public Choice, o autointeresse dos políticos, dos funcionários públicos e dos grupos poderosos acaba por influenciar o desenvolvimento das ações estatais (Ferreira et al., 2005), razão pela qual se busca na competição tributária, entre entes subnacionais, uma forma de neutralizar a tendência expansionista do Leviatã, uma vez que, em regime de competição, seria mais difícil um fortalecimento da máquina pública enquanto monopólio de poder, reduzindo-se, portanto, a possibilidade de ações consideradas nocivas por parte dos burocratas.

Note-se, desde já, que a difusão desse modelo virá contribuir para a propagação de uma noção de eficiência, baseada na competitividade entre as jurisdições, as quais, mediante a desconsideração da importância da dimensão territorial para a compreensão do fenômeno federativo, por-se-ão em posição concorrencial umas com as outras, disputando não só a captação de consumidores-eleitores, mas também de recursos públicos e de investimentos privados, atendendo, assim, aos seus respectivos interesses. A Welfare Economic passa, então, a trilhar um caminho ao encontro da internalização da lógica de mercado no manejo da dinâmica federativa, o que, inevitavelmente, viria a resultar no questionamento sobre a externalidade do Estado em relação à economia. Tais questionamentos dão início à noção de que o fenômeno federativo deveria ser estudado a partir da incorporação dos elementos decisionais dos agentes, ou seja, tomando-se como pressuposto a racionalidade dos atores envolvidos, de modo que os entes públicos estariam submetidos às mesmas regras de comportamento do setor privado, orientadas para a maximização da utilidade individual.

É justamente na ocasião da incorporação desses pressupostos que a Public Choice Theory, a partir da década de 1970, virá a assumir proeminência, enquanto corrente teórica de abordagem da dinâmica federativa. A crise do Welfare State nos países centrais, acompanhada do colapso dos es- 
tados socialistas e da crise do keynesianismo como instrumento de política econômica, deu espaço para a chamada "reação conservadora", encabeçada por teóricos como Milton Friedman e Robert Lucas, ${ }^{8}$ sob o argumento de que a crise mundial, experimentada a partir de 1973, teria sido causada pelas políticas keynesianas, assim como pelos compromissos fiscais assumidos pelo Welfare State. A partir dessas transformações, difundiram-se, fortemente, as ideias de "eficiência", de "competitividade" e de "equilíbrio macroeconômico", sobrepostas, então, ao consenso keynesiano, por sua vez, voltado para o crescimento e o pleno emprego. É em meio a esse contexto que a Public Choice Theory se fortalece enquanto corrente teórica que, concomitantemente à desaprovação de alguns supostos da teoria econômica anterior - como, por exemplo, a externalidade do Estado-, se mantém de mãos dadas com a teoria neoclássica. Essa corrente acredita num modelo de Estado tão eficiente quanto o mercado, porém, não para realizar trocas mercantis (Affonso, 2003; Przeworski et al., 1988, apud Affonso, 2003).

A emergência dessa nova escola se caracteriza pelo rompimento das barreiras antes existentes entre a economia e a ciência política, já que, dada a necessidade de mudança metodológica evidenciada pelas críticas à externalidade do Estado, a solução encontrada para a continuidade do núcleo da formação neoclássica foi a incorporação dos pressupostos do individualismo metodológico na identificação dos determinantes da ação estatal. Assim, pode-se dizer que houve uma espécie de generalização das regras de conduta dos agentes privados, passando o setor público (políticos e burocratas) também a ser concebido como ente maximizador da utilidade, guiado pelo autointeresse e pelas expectativas racionais. Essa análise mercantil do contexto político não poderia deixar de ver o comportamento do Welfare State intervencionista como uma ação movida pelo "interesse" de algum agente, em vez de, efetivamente, se destinar à correção das falhas de mercado (Affonso, 2003).

Considerado o fundador da teoria da escolha pública, o economista James Buchanan identifica o federalismo como meio de promoção da liberdade individual, da democracia eficiente e dos valores da comunidade (Lynch, 2004), fundamentos que atribuem significativo relevo à soberania do indivíduo, no exame das relações federativas. Nessa perspectiva, a extensão dos princípios da economia de mercado para a esfera política faz com que os Estados se comportem como fornecedores, em condição de permanente concorrência entre si (Buchanan, 1996).

Para Buchanan (1996), a constituição normativa da estrutura política deve estar voltada para "completar" o mercado, ainda que se deva admitir a situação de coerção existente sob aquela égide, estando todos os sujeitos submetidos às suas decisões. É com base na constatação dessa condição de coerção estatal que o federalismo aparece como um mecanismo capaz de introduzir a essência das características de mercado na política, visto que a necessidade de organização da produção e transferência de bens requer a garantia de minimização dessa coerção e, concomitantemente, a maximização da soberania individual. Diante disso, a constituição da dinâmica federativa competitiva oferece a possibilidade de limitação do poder do governo central e, ao mesmo tempo, de contenção da potencial exploração dos cidadãos pelas unidades subnacionais. A função do governo central seria, então, a de apenas demarcar alguns parâmetros a serem seguidos pelos demais entes, a fim de que eles, no exercício da competitividade, não viessem a se afastar do padrão de eficiência global (Buchanan \& Tullock, 1993; Buchanan, 1995, 1996).

Essa perspectiva acredita que o federalismo descentralizado e competitivo viria a beneficiar os cidadãos que, podendo circular entre os distintos territórios, poderiam exigir 
ação estatal mais eficiente na composição das políticas públicas (Lynch, 2004). Dessa forma, a abordagem neoliberal da dinâmica federativa prescreve o enfraquecimento do poder do governo central, aliado à inibição de possíveis tentativas de intervenção por parte das províncias, constituindo-se, assim, uma espécie de descentralização/centralização específica, para promover o livre mercado. Seus precursores antecipam-se às críticas, arguindo ser a limitação da autoridade do Estado, em diferentes níveis, um mecanismo de prevenção do autoritarismo, uma vez que, se o poder estiver em mãos separadas, nenhum ente poderá traçar limitações, por exemplo, à circulação territorial (Harmes, 2007).

A visão otimista de Buchanan e Tiebout acerca da competição horizontal como dispositivo atinente à compensação dos possíveis excessos do governo central compõe, portanto, um desenho federativo dos governos nacionais como forma de preservação das forças de mercado (Volden, 2004). A apologia à competição interjurisdicional, em convergência analítica com os microfundamentos da Public Choice voltados para a introdução das regras de comportamento individual no contexto da estrutura federativa -, opõe-se ao modelo cooperativo de federação presente no Welfare State. Por essa perspectiva, o Estado deveria, então, estimular a competição interjurisdicional, por ser o federalismo descentralizado uma oportunidade de melhorar as condições de informação e mobilidade (Dye, 1990).

Outro importante teórico, responsável pela abordagem do federalismo com base nos pressupostos da escolha racional, foi Willian Riker, autor da obra Federalism: Origin, Operation, Significance (Riker, 1964), caracterizada pela clara intenção de aplicar a nova metodologia (individualismo metodológico $)^{9}$ à abordagem da dinâmica federativa. Seus argumentos partem de uma noção do fenômeno federativo como resultado de barganhas institucionais, em que a pró- pria natureza das negociações políticas dificulta o alcance de uma solução equilibrada, tendendo sempre à centralização e, até mesmo, ao unitarismo. Sob essa ótica, a dominação exercida pelo centro colocaria os entes subnacionais à mercê do governo central, sendo tarefa dos políticos racionais evitar tal ocorrência (Filippov, 2005).

Em meio ao entendimento pela mudança de metodologia na explicação do funcionamento do setor público, Oates (1990) aparece como um dos principais estudiosos da questão. ${ }^{10}$ Tomando a direção analítica de internalização do aspecto decisional (racionalidade privada) na estrutura estatal, o modelo trazido por Oates e Schwab (1988), embora se afigure enquanto uma derivação da corrente teórica do trabalho de Tiebout (Acir, 1991), centra-se na mobilidade do capital e não das famílias (Kenyon, 1997). Dedicado aos desdobramentos da competição interjurisdicional para a atração de capital, Oates (1990) chega a concluir que, se todos os agentes (governos subnacionais) adotarem o mesmo comportamento, a competição passará a ser ineficiente, de sorte a todos os locais aumentarem os custos de decisão para a alocação de investimentos privados em seu território (Wilson, 1999). ${ }^{11}$ Assim, essa perspectiva adverte que, em alguma medida, a centralização na coordenação das políticas pode propiciar melhor capacidade de internalização das externalidades interjurisdicionais (Oates, 2005). ${ }^{12}$

Além do modelo de Oates e Schwab (1988), outro derivado do modelo de Tiebout é o de McGuire (1991), o qual se refere à problemática da "competição destrutiva" por meio do argumento de que os indivíduos teriam preferência pela redistribuição, e, com base nisso, as jurisdições seriam estimuladas a concederem incentivos para atrair empresas e indivíduos ricos, para, a partir daí, com o consequente aumento de arrecadação, poder reduzir a tributação sobre os mais pobres e melhorar o fornecimento de serviços públicos. O real problema, diante desse quadro, seria o fato de 
todas as jurisdições comportarem-se de modo a conceder incentivos, o que significaria, inevitavelmente, perda da eficiência alocativa em razão da concorrência destrutiva. Para evidenciar tal perda de eficiência, em busca de uma solução ótima, esse autor utiliza-se da analogia com a "teoria dos jogos", identificando a ação de cada jurisdição com base no dilema do prisioneiro ${ }^{13}$ (Kenyon, 1997).

Valendo-se desse instrumental analítico, deduz-se que, assim como no caso original do dilema do prisioneiro, cada Estado tende a oferecer o incentivo fiscal, e, nesse caso, tais ações ocorreriam não pela falta de comunicação ou entendimento entre os competidores sobre a natureza do jogo, mas sim pelo fato de os estímulos do próprio jogo conduzirem os Estados a oferecer os incentivos, haja vista a inexistência de um acordo não competitivo, possivelmente implementado por um agente externo. ${ }^{14}$ Assim sendo, como uma espécie de ponderação acerca da concorrência desordenada - inicialmente defendida pela Public Choice Theory -, a advertência sobre o caráter destrutivo da competição interjurisdicional aparece pela constatação de que a redução individual da tributação se traduziria num jogo de soma negativa para os atores envolvidos, portanto, prejudicial à boa saúde das finanças públicas de todos os jogadores (Acir, 1991; Kenyon, 1997).

Conforme se pode perceber, com o passar do tempo, estudos vieram a relativizar a visão otimista de Tiebout e Buchanan sobre as vantagens da competição interjurisdicional, enquanto mecanismo de contenção dos excessos do governo central. Trabalhos empíricos ${ }^{15}$ passaram, então, a encontrar ineficiências na descentralização proposta pelo federalismo competitivo, dadas as dificuldades impostas ao governo central para articular a política econômica (Volden, 2004). Embora não se tenha deixado de reconhecer o salto representado pela teoria de Tiebout, a concepção de uma dinâmica federativa, baseada na lógica dos mer- cados competitivos, regulados pela mão invisível, passa a ser questionada. Os pressupostos de que cada indivíduo seria guiado pelas matrizes da informação perfeita e do baixo custo de deslocamento, fazendo, assim, uma escolha "eficiente" de onde residir, começam a cair por terra (Schnellenbach, 2005).

As críticas direcionadas à Public Choice Theory acabaram por evidenciar duas limitações internas ao seu escopo: a primeira, consistente na valorização não qualificada da descentralização, responsável pelo estímulo a uma série de forças centrífugas, abrindo mão do papel coordenador do governo central e comprometendo, desse modo, a eficiência alocativa do sistema federativo; a segunda, consubstanciada na restrição do papel do Estado, sob o pretexto de eliminar os riscos de limitação das liberdades individuais pelo Leviatã, sem considerar, entretanto, que os próprios governos subnacionais passariam a exercer monopólio em suas respectivas jurisdições (Affonso, 2003).

Sem abandonar a prerrogativa de fazer do desenho federativo dos governos subnacionais um instrumento de preservação das forças de mercado (Volden, 2004), as mutações no horizonte teórico dos pertinentes estudos dar-se-ão em meio a uma atmosfera em que já são conhecidos os efeitos danosos da competição tributária desordenada e aponta-se a necessidade de regulação - em alguma medida -do mercado, como mecanismo de garantia da eficiência alocativa. ${ }^{16}$ Os maiores desafios passam, então, a gravitar em torno da conciliação entre a competição tributária sem, no entanto, sacrificar o nível de bem-estar, ou seja, sanar os aspectos destrutivos da competição, conservando os benefícios trazidos pela descentralização (Ferreira et al., 2005). Essa percepção das disfunções e das possibilidades, diante do modelo trazido pela Public Choice, virá ensejar a proeminência, no âmbito dos estudos federativos, da escola subsequente, qual seja, a New Institutional Economics, 
emergente em um período caracterizado, em linhas gerais, pela necessidade da realização de ajustes macroeconômicos em diversos países, como forma de conter os efeitos das externalidades negativas.

Embora não se possa traçar delimitação precisa sobre o momento de transição entre as escolas de pensamento, no decorrer das décadas de 1980 e 1990, foi possível identificar progressiva passagem da Pubic Choice Theory para a New Institutional Economics, a qual, desde então, assumiu papel central no âmbito da economia do setor público e, por conseguinte, nos estudos sobre a dinâmica federativa. Essa transição aparece como um sintoma das reformas de Estado, de inspiração neoliberal, as quais pregavam a necessidade de um "ajuste" macroeconômico, como forma de garantir o bom funcionamento dos mercados. Tal como a Public Choice Theory, esta última escola afigura-se como derivação da economia neoclássica, porém, questionando - principalmente a partir da década de 1990 - o papel dominante atribuído ao mercado pela ortodoxia e propondo, dessa forma, a constituição de um desenho institucional capaz de superar a confrontação estéril entre Estado e mercado. Em tempos de crise das "grandes narrativas", a New Institutional Economics emerge como uma teoria abrangente, voltada para a explicação das transformações sociais e econômicas, de um modo geral (Affonso, 2003; Harris et al., 1995).

A fragilidade institucional a que foram submetidos os Estados, no decorrer das décadas de 1980 e 1990, deu-se concomitantemente à proeminência das organizações internacionais, as quais tomaram para si a tarefa de traçar um corpo de princípios e recomendações voltados para a reconstituição da capacidade de ação do Estado, porém, desta vez, conciliando a articulação das ações coletivas ao imperativo da "eficiência”. Um dos documentos que melhor caracteriza esse tipo de prescrição é o relatório anual, de 1997, publicado pelo Banco Mundial, "World Development Report: the state in a changing world", o qual, declaradamente fincado na perspectiva neoinstitucionalista, prega o revigoramento do poder estatal, por meio da extirpação da corrupção e do aumento da eficiência do setor público. $\mathrm{O}$ documento prevê a implementação dessas ações mediante um ganho de participação do cidadão no controle dos atos públicos ${ }^{17}$ e da constituição de normas de direito público transparentes, capazes de viabilizarem o controle recíproco e o autocontrole $^{18}$ dos poderes instituídos (Executivo, Legislativo e Judiciário) (The World Bank, 1997).

Mais recentemente, outro relatório emitido pelo Banco Mundial, em 1999/2000, segue na demonstração das ditas preocupações, abordando de forma mais específica a questão dos riscos inerentes ao processo de descentralização desordenada. O texto pondera não ser a descentralização, em si, boa ou má, haja vista a necessidade de se observar a realidade política de cada país, não se podendo, dessa forma, importar modelos originados em contextos diversos, caracterizados por outras tradições políticas, marcos regulatórios ou direitos sobre a propriedade. Nesse sentido, aos países em desenvolvimento o Banco Mundial direciona advertência dos riscos inerentes à descentralização, evidenciando, para tanto, as más consequências verificadas desde meados da década de $1980 .{ }^{19}$ Sugere, diante disso, aperfeiçoamento das instituições administrativas, como medida de fundamental importância para o desenvolvimento de um processo de descentralização que não perca de vista a articulação de uma política fiscal única ${ }^{20}$ (The World Bank, 2000).

Conforme se pode depreender das recomendações constantes nos relatórios do Banco Mundial, os pressupostos da Public Choice Theory foram, de algum modo, flexibilizados, pois, em se considerando a existência de mercados imperfeitos e da informação imperfeita, ${ }^{21}$ naturalmente, não se poderia deixar de levar em conta o fato de a ação de um 
dado agente individual causar externalidades sobre a ação dos demais.

A New Institutional Economics, embora mantenha consigo a noção de que a competição tributária interjurisdicional traz ganhos de eficiência para o setor público, adverte estarem tais benefícios condicionados à constituição de um arranjo institucional apropriado, capaz de manter a "concorrência" entre os governos subnacionais, dentro dos parâmetros de uma "competição saudável", coibindo, para tanto, o surgimento de práticas e de instrumentos possivelmente nocivos ao entorno sistêmico das relações intergovernamentais. Assim, em contrariedade à analogia estabelecida entre a concorrência intergovernamental e à lógica dos mercados competitivos, desenvolvida por atores privados, a New Institutional Economics reage, criticamente, à "canonização" da competição tributária, enquanto postulado, invariavelmente, promotor da eficiência no setor público (Affonso, 2003).

Em meio a esse contexto de redefinição do papel do Estado, os desdobramentos na esfera subnacional convertem-se em prescrições de restrição financeiro-orçamentária, tendentes a constituírem institucionalidades adequadas ao capitalismo financeirizado. As reformas institucionais passam a propor, então, o alinhamento dos governos subnacionais a uma disciplina fiscal conhecida como de restrição orçamentária forte, a Hard Budget Constraint (HBC), ${ }^{22}$ concebida, nesse caso, enquanto um mecanismo de conciliação entre as restrições impostas a esses governos e a descentralização fiscal e política. O redesenho institucional proposto pela HBC assenta-se na noção de accountabillity, visando garantir a responsabilização das esferas subnacionais por eventual indisciplina fiscal, sem que, no entanto, para isso, tenha o governo central de incidir em altos custos financeiros, reputacionais e políticos, por não socorrer as demais unidades (Vargas, 2006). Como alternativa teóri- ca para a ilustração de tal fenômeno, Oates (2005) propõe a utilização da "teoria dos jogos", ${ }^{23}$ sugerindo, em citação de Inman (2003), uma analogia com o dilema do prisioneiro, na qual o governo central deveria afirmar a impossibilidade de resgate da dívida de qualquer dos entes subnacionais, para que, a partir de então, estes últimos viessem a avaliar a viabilidade dessa pretensão e, em seguida, tomar suas decisões orçamentárias.

O redesenho institucional, então vivido pelo mainstre$a m$, afina-se à concepção de que os elementos definidores do federalismo, enquanto forma organizatória de Estado, não incluem como necessária a possibilidade de os entes subnacionais participarem da tomada de decisão pelo governo central. Nesse esteio, as relações intergovernamentais passam a se pautar em quatro elementos básicos: 1) a atribuição aos governos locais de uma espécie de "autonomia programática”, ou seja, o poder de decisão para apenas alguns subconjuntos da política econômica; 2) a aplicação de forte restrição orçamentária (HBC), com impedimento de acesso ilimitado a crédito, porém, com financiamento de despesas a partir de receitas originárias, em parte, de outro ente; 3) a preservação do mercado comum, não se podendo impor barreiras ao livre fluxo de bens, capital e trabalho; e 4) a consolidação de um sistema, razoavelmente, institucionalizado, a fim de que o governo não possa modificá-lo aleatoriamente (Sorens, 2010).

Conforme se pode perceber, embora evidentes os prejuízos causados pela competição interjurisdicional, em meio a um regime de descentralização desregulamentada, a competitividade foi mantida como elemento salutar à promoção da eficiência do setor público, desde que, por certo, acompanhada de mecanismos institucionais de contenção dos comportamentos predatórios. Destarte, não se pode deixar de mencionar que, com o advento da globalização e da mobilidade internacional dos recursos, se tornou cada vez mais 
difícil medir, empiricamente, as consequências dessa forma de competição, pois, uma vez traçada em escala global, seus determinantes passam a girar em torno dos sistemas tributários nacionais, de modo geral (Acir, 1991; Goodspeed, 1998).

A dificuldade de mensuração dos efeitos da competição tributária ocorre por, entre outros fatores: 1) o sistema ser complexo com tendência a não transparência sobre os seus determinantes; 2) existir variedade de fatores, para além dos impostos, tais como fatores locais; 3) haver dificuldade de informação acerca dos benefícios derivados dos gastos públicos, não sendo possível saber se a concorrência é boa ou ruim; e 4) coexistirem várias políticas públicas no mesmo sentido, inviabilizando qualquer tentativa de delimitação isoladora dos efeitos da concorrência fiscal (Goldspeed, 1998). Como a literatura pertinente oferece poucas evidências sobre ganhos e perdas da competição interjurisdicional, num panorama globalizado, cresce a necessidade de estudos empíricos tendentes a suprir essa fundamental lacuna teórica. Assim sendo, tendo em vista a ausência de inferências conclusivas nesse sentido, propõe-se evitar medidas extremas na condução do processo, seja para coibir, seja para aprofundar a difusão da concorrência entre os entes. Enquanto isso, resta a percepção de que o aumento da mobilidade dos fatores de produção e dos fluxos de comércio traz consigo uma pressão pela harmonização das políticas internas - inclusive a tributária - aos padrões estabelecidos internacionalmente (Ferreira et al., 2005).

Conforme se pode perceber, a New Institutional Economics, compreendida como uma derivação da Public Choice Theory, não consegue desgarrar-se dos pressupostos inerentes ao individualismo metodológico neoclássico, uma vez que, mesmo relativizando a noção de racionalidade instrumental (racionalidade limitada), conserva o hábito de explicar a dinâmica federativa com base nos microfundamentos da ação orientada para a maximização. Muito embora se insiram elementos sociopolíticos na composição da análise, a consolidação das instituições apresenta-se, unicamente, como mecanismos de viabilização de uma maximização utilitária, dentro dos moldes da eficiência econômica. O individualismo metodológico persiste, então, enquanto forma, não só de análise, mas de concepção da própria realidade, nesses termos, percebida enquanto mero agregado de racionalidades individuais, operantes em meio aos mecanismos institucionais, instrumentalmente estabelecidos. Ao fincarem seus pressupostos em esquemas analíticos, cuja ação individual representa o primeiro determinante das transformações sociais, as teorias hegemônicas restringem o seu escopo analítico aos microfundamentos, negligenciando o condicionamento histórico-estrutural do objeto e até a própria proeminência.

\section{3_A Inadequação do individualismo metodológico ao fenômeno federativo e a necessidade de uma abordagem totalizante}

Constatadas as limitações inerentes aos pressupostos utilizados pelas teorias hegemônicas da economia do setor público na análise da competitividade interjurisdicional, importa apontar, aqui, uma alternativa teórica voltada para a compreensão desse fenômeno baseando-se em outros postulados de investigação. Nesse intento, o presente tópico se destina, primeiramente, a evidenciar a insuficiência do individualismo metodológico enquanto pressuposto analítico de abordagem da dinâmica federativa, sugerindo a captação dos seus efetivos determinantes a partir da noção de totalidade concreta. ${ }^{24}$ Assim, a abordagem totalizante, ora proposta, caminha no sentido de considerar as contradições expressas na própria materialidade institucional do arranjo federativo, concebendo-o como uma matriz espaço-temporal constituída em condicionamento recíproco 
com o padrão de acumulação e a conjuntura na qual se insere. Essa perspectiva compreende a constituição histórico-social do espaço em interdependência com as estratégias organizativas proeminentes em cada contexto, percebendo o atual estágio constitutivo da arquitetura federativa dos Estados como uma adequação às pressões exercidas pela dinâmica de competitividade internacional entre eles.

A tentativa de compreensão dos fenômenos sociopolíticos e econômicos valendo-se de concepções advindas de um plano micro, ${ }^{25}$ tomando-se como célula de análise a noção hipotética (ea-histórica) de indivíduo egoísta - movido por uma racionalidade utilitária, voltada unicamente para a maximização dos próprios interesses -, não atende ao escopo analítico exigido pelo federalismo, visto que a própria heterogeneidade dos conflitos que o envolvem e a sua percepção enquanto fenômeno coletivo e territorial não permitem considerar indivíduos atomizados como ponto de partida para a sua análise, tampouco como os únicos verdadeiros agentes desse processo. A abordagem da questão federativa não pode negligenciar a noção de totalidade concreta, enquanto postulado investigativo dos seus determinantes, já que a própria dinâmica de funcionamento a revela como fração de um todo, consubstanciado nas macroestruturas, características do padrão de acumulação hegemônico. Embora não se possa deixar de reconhecer a efetiva existência de uma disputa entre os agentes envolvidos na competição interjurisdicional, por outro lado, os determinantes desse acirramento não podem ser atribuídos, exclusivamente, ao pressuposto impulso maximizador desses atores. Para além dessa perspectiva, a disposição de tais microfundamentos deve ser concebida em consideração da sua interdependência constitutiva com a correlação das forças produtivas e o estágio de desenvolvimento capitalista, condicionando, reciprocamente, a composição da materialidade institucional federativa.
A difusão do individualismo metodológico pelas diferentes áreas do conhecimento é colocada por Przeworski (1988, p. 5) como parte de "um esforço deliberado para impor o monopólio do método econômico a todo estudo da sociedade", pois, consoante os fundamentos da escola neoclássica, ${ }^{26}$ todos os acontecimentos poderiam ser enquadrados em apenas duas categorias: as de "fenômenos econômicos e fenômenos aparentemente não-econômicos" (Przeworski, 1988, p. 5), ${ }^{27}$ submetendo-se, assim, todos os referenciais teóricos das ciências sociais à predominância metodológica das chamadas "escolhas racionais" individuais. O imperativo trazido por essa doutrina subjuga, então, os conceitos das diversas áreas ao seu fornecimento de "microfundamentos para os fenômenos sociais", como forma de calcar "toda a teoria da sociedade nas ações dos indivíduos concebidas como orientadas para a realização de objetivos racionais" (Przeworski, 1988, p. 5).

Alinhadas a essa perspectiva, as escolas de pensamento da economia do setor público (Welfare Economics, Public Choice e New Institutional Economics) abordam a dinâmica federativa e, por assim dizer, a competição interjurisdicional, tomando os atores envolvidos como elementos, originariamente, isolados, cuja ação é, predominantemente, voltada para a maximização racional do seu autointeresse. Negligencia-se, desse modo, a existência de uma estrutura macrossocial, cuja essência vai além da mera agregação das racionalidades individuais. Por essa perspectiva, os movimentos componentes das relações entre as jurisdições não são percebidos enquanto fração de uma totalidade concreta, ou seja, como produto e produtores de um contexto historicamente condicionado, em cujas contradições esboçam os fundamentos de um modo de produção e reprodução social específicos.

A tomada da noção de indivíduo como célula primeira de análise e explicação dos fenômenos macrossociais conduz a um inevitável reducionismo sobre os determinantes 
desse fenômeno particular, o que, na opinião de Affonso (2003, p. 201-202), culmina por inviabilizar a efetiva compreensão da natureza específica do objeto "federalismo" e do "Estado federal", uma vez que a abordagem teórica desse tema demanda tratamento de realidades heterogêneas, em diferentes dimensões ${ }^{28}$ Por essa razão, a adoção dos pressupostos do "individualismo metodológico restringe - senão impede - a mainstream theory de captar as dimensões centrais da problemática do federalismo" (Affonso, 2003, p. 201-202).

A inadequação do fenômeno "federalismo" aos pressupostos do individualismo metodológico tem origem na tentativa de concebê-lo enquanto mero mecanismo de alocação do poder político sob uma perspectiva monista de maximização. Em realidade, a essência desse objeto manifesta-se na incorporação da diversidade das identidades individuais e coletivas, assim como da pluralidade de racionalidades, de forma concatenada, ou seja, considerando as suas diferenças, mas, ao mesmo tempo, concebendo-o enquanto um todo dinâmico, composto por uma heterogeneidade de elementos e relações (Théret, 1995, 2004).

Especificamente no que tange à competição interjurisdicional, os entes federativos são tidos, por essa perspectiva, como se fossem, propriamente, agentes racionais maximizadores, atuantes numa espécie de "jogo", cuja determinação do resultado depende, unicamente, da soma das ações e dos comportamentos dos agentes envolvidos. Diante disso, em sendo os membros do sistema federativo considerados agentes egoístas, o contexto predominante na relação entre eles é de desconfiança e de incerteza, de modo que as próprias "regras do jogo" e a suposta natureza dos agentes dificultam a implementação de uma postura cooperativa entre eles. $\mathrm{O}$ pacto federativo, expresso por meio da Constituição Federal, passa a ser concebido, então, como uma espécie de "contrato", capaz de reduzir o nível de incerteza do ambiente, possibilitando, de certo modo, a consecução de ações cooperativas e reduzindo a assimetria entre os agentes envolvidos, percebendo a dinâmica de funcionamento deles a partir de uma forma única de racionalidade (Abrucio et al., 1999; Varsano, 1997).

Em alternativa a tais reducionismos, a efetiva compreensão dos determinantes da dinâmica federativa, em vez de partir de suposições individualistas, deve se debruçar sobre os mecanismos encarnados na própria materialidade institucional desse arranjo, o qual, por sua vez, - se concebido enquanto fração de uma totalidade concreta -, esboça as formas organizativas fundamentais sob as quais se assentam as bases materiais do padrão de acumulação. Em sendo o federalismo um complexo no qual coexistem várias ordens políticas e jurídicas autônomas e interdependentes entre si - dentro da estrutura do próprio Estado -, importa considerar a constituição das formas institucionais estatais em integração com as especificidades da sua conjuntura. Nesse sentido, os contornos assumidos pelo federalismo vão sendo delineados em condicionamento recíproco com o processo de acumulação, assumindo feições "adequadas" aos movimentos de organização e reorganização do espaço, propícios à reprodução desse sistema.

Por essa perspectiva, a estruturação territorial se compõe em meio às modificações fundamentais do contexto histórico, inseridas conforme a organização das matrizes de espaço e de tempo, constitutivamente interdependentes, no âmago das relações de produção e da divisão social do trabalho. ${ }^{29}$ As formas de apropriação histórico-social do espaço estão condicionadas, portanto, segundo os diferentes modos de produção, os quais, por seu turno, esboçam distintas formas organizativas, conforme suas respectivas particularidades. Instaura-se, assim, um processo de concomitante fragmentação e homogeneização, composto de: de um lado, uma segmentação serial do espaço, mediante o parcelamento sequenciado das etapas produtivas - tal como numa di- 
visão taylorista do trabalho na cadeia de uma fábrica - e; de outro, a uniformização, capaz de garantir o mínimo de homogeneidade do espaço social, necessária aos movimentos de reprodução ampliada do capital e generalização das trocas e fluxos monetários (Poulantzas, 1980). Desse modo, a conjugação das forças sociais presentes num dado contexto histórico edifica as matrizes espaço-temporais enquanto expressão de uma racionalidade hegemônica, compondo a base das articulações entre espaço e tempo no movimento de apropriação do espaço capitalista (Nicolas, 1998). ${ }^{30}$

A produção, o consumo, o padrão de acumulação, a cultura e o estilo de vida se unem como uma espécie de "coerência estrutural", composta em meio a uma totalidade de forças produtivas e relações sociais, definidoras dos processos operativos que delimitam a formação dos espaços regionais. A produção e o consumo dentro de um dado espaço histórico-social exige certa "coerência territorial", voltada para o estabelecimento de diretrizes sobre como e onde o capital pode circular sem que os custos de tempo e movimento excedam os benefícios obtidos em face do tempo de rotação ${ }^{31}$ socialmente necessário. Essa "coerência territorial" se torna mais marcante quando representada, formalmente, pela figura do Estado, o qual, por meio da composição de políticas públicas e da própria armação institucional reforça, informalmente, a criação de culturas e consciências nacionais, regionais e locais (Harvey, 2004, 2007).

Por outro lado, embora a "coerência estrutural" - refletida numa "coerência territorial" - pareça, num primeiro plano, conveniente à reprodução do capital em geral - por possibilitar a remoção dos obstáculos espaciais a sua livre circulação e valorização -, as contradições inerentes ao próprio movimento de apropriação histórico-social do espaço desencadeiam processos que acabam por minar essa mesma coerência. Tais processos se relacionam com algumas das características primordiais do capitalismo, quais sejam: a) a acumulação e a expansão, em conjunto com a necessidade de produzir e absorver os excedentes da força de trabalho e de capital, causando pressões sobre dada região, no sentido de promover a ampliação (exportação) de capitais e atração de mão de obra (imigração); b) as revoluções tecnológicas, que libertam, parcialmente, a produção e o consumo das restrições espaciais; c) a luta de classes, enquanto possíveis ensejadoras do deslocamento de capitalistas ou trabalhadores em busca de condições mais propícias a sua proeminência e; $d$ ) as mudanças nas formas de organização capitalista (por exemplo: ascensão do capital financeiro, das empresas multinacionais, terceirização de etapas produtivas, etc.), possibilitando controle progressivamente mais intenso sobre espaços cada vez mais extensos, por parte do grande capital. $\mathrm{O}$ arrefecimento da "coerência estrutural" por esses processos ganha ênfase, portanto, com a ampliação da divisão internacional do trabalho, o qual, a depender do contexto histórico-concreto em que se materialize, pode tornar a interdependência regional mais significativa que a coerência regionalmente instituída, taxando os limites territoriais de "inadequados" e forçando a sua modificação (Harvey, 2007).

$\mathrm{O}$ estabelecimento de um interesse geral e a institucionalização dos compromissos sob matrizes espaço-temporais específicas fazem com que as estratégias de acumulação e os projetos hegemônicos adiem e desloquem seus custos materiais e sociais para além dos próprios limites espaciais e temporais. Assim, distintas escalas de ação e horizontes temporais podem ser utilizadas enquanto forma de "correção" espaço-temporal das contradições estruturais e dilemas estratégicos do capitalismo (Jessop, 2000a). Nesse sentido, a "coerência estrutural" necessária à reprodução e regulação do capital se dedica à "formulação-realização" de estratégias específicas de acumulação, desdobradas sob matrizes espaço-temporais também específicas, as quais, 
por sua vez, buscam resolver conflitos entre o "capital em geral" e o "capital particular", a partir da construção de um “interesse econômico geral", inserindo ou marginalizando determinados interesses capitalistas (Jessop, 2000b).

A arquitetura institucional do Estado assume, dessa forma, funções "adequadas" ao processo de acumulação, em conjunturas historicamente concretas, por meio da constituição de seletividades estratégicas, incrustadas na própria materialidade institucional, projetadas em razão de forças sociais particulares (Jessop, 2009; Poulantzas, 1980). Os traços organizativos fundamentais do ente público vão sendo, então, delineados por meio da instituição de regras operativas de seleção, voltadas para a atualização de uma única seção ou área de resultados possíveis, produzindo certa uniformização ou consistência dos eventos. Por esses contornos, a materialidade institucional do Estado vai sendo formada mediante a composição de "filtros sistêmicos" que dão aos processos político-administrativos interesse específico direcionado à reprodução do sistema de acumulação, constituindo, dessa forma, uma estrutura organizativa pública em afinidade com os objetivos estratégicos de um padrão de racionalidade garantidor de um escopo restrito de possibilidades (Offe, 1974, 1990). Essas seletividades esboçam matrizes espaço-temporais configuradas enquanto pressupostos das relações de produção, organizando as práticas sociais conforme as estratégias de acumulação desenvolvidas sob a "coerência estrutural" e seus movimentos contraditórios (Harvey, 2004; Jessop, 2000a; Poulantzas, 1980).

O processo de formação do Estado, segundo as seletividades estratégicas incrustadas no seu aparato institucional, esboça os significados das matrizes espaço-temporais que segmentam e circunscrevem o território nacional, moldando seus sistemas políticos e econômicos (Jessop, 2009; Poulantzas, 1980). Embora a racionalização da organização do espaço, de modo geral, traga consigo uma noção de pro- gresso, a qual pressupõe a destruição de barreiras espaciais (aniquilação do espaço pelo tempo),, ${ }^{32}$ a composição ideal da estruturação territorial não é a mesma em todos os contextos histórico-concretos, já que uma matriz espaço-temporal, constituída num dado estágio de desenvolvimento das forças produtivas, pode não resultar "adequada" para o padrão de acumulação em momentos posteriores. Assim, a ampliação da mobilidade do capital e o consequente acirramento da dinâmica competitiva entre os lugares fazem com que os correspondentes esforços, empreendidos pelos Estados, ao invés de induzirem à produção de espaços diferenciados, acabem por constituir matrizes espaço-temporais cujos moldes e padrões organizativos reproduzem lugares idênticos. Insertos num contexto marcado pela homogeneização dos parâmetros internacionais, os Estados se submetem ao movimento contraditório inerente à própria dinâmica competitiva entre os espaços, a qual, por sua vez, manifesta um paradoxo central: quanto menos significativas são as barreiras espaciais, maior a sensibilidade dos capitais às variações de localização e, por conseguinte, maior o incentivo para os lugares se diferenciarem; em constituição dessas diferenciações, os lugares passam a oferecer vantagens aos capitais, ajustando-se, assim, aos padrões de competitividade internacionais, logo, tornando-se, cada vez mais, homogêneos (Harvey, 2004).

Os desafios inerentes às transformações espaço-temporais da atualidade passam pelo redesenho da geografia econômica, segundo as metamorfoses do movimento do capital e sua acumulação (Brandão, 2004), constituindo um cenário cujas vantagens competitivas das nações se materializam conforme o seu acoplamento estrutural aos diferentes espaços econômicos, mediante o ajustamento às ordens institucionais preceituadas como "adequadas" aos mercados internacionais. A partir daí, as estratégias adotadas como preferenciais pelos Estados passam a privilegiar 
políticas destinadas à constituição de uma base territorial atrativa para as firmas (capital móvel), constituindo-se modos específicos de regulação, historicamente contingentes (Jessop, 2000a). Nesse sentido, a institucionalização dos compromissos sob matrizes espaço-temporais específicas passa a ser guiada pelo objetivo de articular coalizões dentro do Estado nacional, como forma de adquirir vantagens competitivas no mercado mundial, pois a transformação do Estados em "Estados competitivos" submete as suas estruturas internas às pressões da competitividade internacional, obrigando-os a internalizar, cada vez mais, os contornos institucionais preceituados pelas estratégias de acumulação, delineadas pelos organismos supranacionais, como, por exemplo, o Banco Mundial (Hirsch, et al., 2010; Hirsch, 1996; Jessop, 2008; Lengyel, 1997).

Essa subordinação das ações estatais aos ditames da economia globalizada, mediante o preenchimento de condições voltadas para a atração de capital global móvel (Bonefeld, 1999), dá-se, entre outros, por meio da concessão de isenções tributárias, subsídios e desregulação (Jessop, 2008). Esses mecanismos consolidam o processo de internacionalização dos aparatos estatais individuais, ampliando, ao mesmo tempo, o seu grau de dependência em relação aos demais Estados e à economia internacional. Quanto maior o nível de integração dos Estados ao mercado mundial, maior a sua exposição às pressões competitivas recíprocas e, por conseguinte, menor a sua margem de manobra para direcionar a própria economia e políticas sociais, bem como determinar, autonomamente, a sua autoconfiguração institucional. Entretanto, por outro lado, não se pode dizer que esse processo consiste num simples enfraquecimento externo dos Estados nacionais, uma vez que, em realidade, se trata de uma estratégia de autotransformação, protagonizada por eles próprios, ao engendrarem uma reconfiguração dos espaços na qual o próprio nível dos "Estados individuais" declina em importância (Hirsch et al., 2010). A escala nacional perde, então, primazia, porém, sem deixar de ser uma escala privilegiada, por meio da qual se organizam os demais níveis de articulação, permanecendo, dessa forma, como o principal ponto de ancoragem do processo de acumulação (Jessop, 1999, 2000b, 2008).

Com base nesse cenário, as lutas sociais passam a girar em torno da discussão sobre qual escala deve predominar, ensejando, nesse sentido, uma proliferação de escalas e temporalidades de ações institucionalizadas de regulação, constituídas em meio ao desenvolvimento de novos mecanismos logísticos e tecnologias organizativas, assim como de arranjos institucionais com novos horizontes de ação espaço-temporais e arquiteturas mais amplas, capazes de reordenar as relações entre diferentes níveis políticos. Desse modo, o aumento da necessidade de coordenação supranacional e a possibilidade de um ressurgimento subnacional só ampliam as possibilidades de o Estado nacional mediar essas escalas de ação, por meio do aperfeiçoamento da sua capacidade estratégica de operação em diferentes escalas (Jessop, 2000b; 2008).

Essa relativização das escalas de ação estratégica, em meio ao cenário de competitividade internacional,faz com que algumas políticas públicas se voltem para o atendimento à necessidade de coesão interna, como forma de ampliação da competitividade do Estado na economia global. Isso se reflete na subordinação de âmbitos de ação como: a redistribuição financeiro-fiscal entre os diferentes níveis de governo; o aumento da pressão sobre a responsabilidade fiscal desses e; o redesenho das transferências sociais para fazê-los mais produtivos (Jessop, 2008). Tal dinâmica vem demandando maior envolvimento e alinhamento das unidades federativas subnacionais aos esforços do Estado para atender às exigências dentro dos parâmetros de competitividade internacional (Saraiva, 2004). Nesse sen- 
tido, os territórios nacionais, uma vez concebidos enquanto espaços nacionais da economia internacional, acabam por sofrer pressões para empreenderem a uniformização e o fortalecimento da sua coesão interna, transformando a chamada "unidade na diversidade" - consagrada pelo federalismo - em uma "inadequação aos tempos da nova história com a emergência da globalização" (Santos, 2001, p. 96).

Nesse cenário, passam a surgir momentos de oposição entre o conteúdo normativo do território e as exigências da "coerência estrutural", engendrada pelo padrão de acumulação. Emergem, desse modo, eventuais embates entre o dinheiro globalizado e as diversas instâncias político-administrativas do Estado. As frações do território nacional veem-se, então, pressionadas a se ajustar, enquanto espaços de fluxos da temporalidade globalizada, posicionando-se segundo o ordenamento do espaço total de acumulação (Santos, 2001, p. 96; 2006; Harvey, 2007).

A necessidade de neutralizar as determinações autodestrutivas e as forças desagregadoras da dinâmica competitiva capitalista faz com que o próprio aparato institucional do Estado seja afetado pela onda homogeneizadora dos mercados mundiais, na medida em que o ente público precisa alinhar o seu arcabouço legal-institucional às pressões do centro hegemônico (Brandão, 2004). Isso traz dificuldades para as discussões jurídico-institucionais relativas à definição da forma adequada de organização do Estado federativo, afetando a viabilidade da sua dinâmica, principalmente, em países com territórios extensos e populações heterogêneas. Em razão disso, o desenho assumido pela organização territorial, política e administrativa do Estado se distancia de um dos fundamentos básicos do federalismo, qual seja, a garantia da coexistência de autonomias jurídico-políticas, em conjunto com a unidade institucional e territorial da nação. O figurino federativo, ao invés de consagrar a diversidade e a unidade dos níveis de governo, vai sendo reorganizado segundo três processos fundamentais: a internacionalização do capital; a "deslocalização" ou a realocação espacial permanente das plantas produtivas e equipamentos nos espaços abertos e; a homogeneização das políticas econômicas voltadas para a estabilização (Fiori, 1995).

É justamente em meio a esse processo de crise da federação, intensificada pelas pressões competitivas sofridas pelos Estados nacionais (Affonso et al., 1995), que os adeptos da New Institutional Economics preceituam, atualmente, a regulação e a coordenação das ações dos governos subnacionais pelo Estado nacional. Isso não significa dizer, entretanto, um posicionamento no sentido de garantir a consecução dos fundamentos básicos do federalismo, pois, ao contrário, a finalidade última dessa perspectiva se traduz em, unicamente, assegurar maior nível de eficiência dentro do contexto concorrencial globalizado. A composição do pacto federativo passa, então, a ser direcionada para a constituição de mecanismos de descentralização negociada, cuja preocupação maior é esculpir um desenho institucional "adequado" ao atual padrão de acumulação, o qual, ao menos no presente estágio de correlação das forças produtivas, preceitua uma composição federativa baseada em diagnósticos de disciplina fiscal forte e restrições aos entes subnacionais (Oliveira, 2007).

Conforme se pode perceber, os efetivos determinantes da dinâmica federativa, interferentes na composição da competição interjurisdicional, não se encontram localizados, unicamente, na orientação individual maximizadora dos seus atores. A compreensão dos elementos basilares da sua dinâmica de funcionamento passa também, inevitavelmente, pela abordagem dos seus macrofundamentos, mediante a identificação das contradições materiais objetivas, incrustadas na própria materialidade institucional do arranjo federativo. A percepção desse arquétipo deve 
considerar, portanto, o condicionamento recíproco entre a sua composição e o padrão de acumulação. Desse modo, para além de mero agregado de racionalidades individuais - suposto pelas teorias hegemônicas da economia do setor público -, o escopo analítico utilizado para o estudo desse fenômeno deve considerar a interdependência entre a reestruturação organizativa das estratégias de acumulação e os contornos assumidos pelas matrizes espaço-temporais em contextos historicamente específicos.

\section{4_Considerações finais}

Embora os obstáculos impostos ao estudo da dinâmica federativa - em razão da hegemonia do individualismo metodológico - pareçam estar adstritos, exclusivamente, ao plano analítico, tais limitações não se esgotam na "forma" de apreensão do objeto estudado, mas sim na própria "concepção" desse. Nesse sentido, a constatação dos percalços inerentes à apreensão da competição interjurisdicional aponta para uma discussão não somente sobre o método empregado no seu conhecimento, mas também, e principalmente, sobre em que consiste a própria essência desse fenômeno e quais os efetivos determinantes das suas transformações. As dificuldades atinentes à investigação da dinâmica federativa extrapolam, desse modo, a dimensão metodológica da questão, pois, o cerne do debate ora apresentado parece estar localizado, em verdade, no plano ontológico, haja vista a necessidade de percepção desse objeto enquanto produto e produtor de um contexto sócio-histórico determinado. A tomada do real como um complexo de relações e determinações diversas conduz à concepção do arranjo federativo enquanto fenômeno constitutivamente interdependente à correlação das forças produtivas, materializado em meio à "coerência estrutural" exercida sobre a apropriação histórico-social do espaço.
Admitindo-se a existência de uma dinâmica competitiva entre os atores envolvidos nesse fenômeno, importa conceber os seus determinantes como fração de uma competitividade estrutural, determinada, material e historicamente, pela interdependência entre os macros e microfundamentos no movimento de composição do real.

Sugere-se aqui, valendo-se dessa perspectiva, a investigação da competição interjurisdicional mediante a sua concepção enquanto fração de uma totalidade concreta, a qual expressa, nos mecanismos do seu movimento, a própria dinâmica de funcionamento do seu todo. Nesse sentido, a observação dos contornos assumidos pela materialidade institucional do arranjo federativo e o seu cotejo em face das matrizes espaço-temporais - constituídas em meio ao padrão de acumulação contemporâneo - aparece como uma direção de investigação capaz de auxiliar a efetiva captação dos seus determinantes. Assim, espera-se desvelar as reais categorias que compõem a dinâmica de funcionamento dessa estrutura organizativa.

\footnotetext{
Notas

${ }^{1}$ Embora a maioria dos autores não proceda na identificação das tipologias de competição interjurisdicional, vale mencionar a ocorrência das três principais formas: 1) na ocasião em que as unidades competem quanto ao fornecimento de um pacote de bens públicos, tentando melhorar sua qualidade, reduzir os custos de adaptação e atender às preferências dos agentes; 2) quando competem por fundos (receitas) para financiar a provisão de bens públicos ao menor preço tributário possível;
}

\author{
e 3) quando buscam atrair \\ investimentos privados para os \\ seus respectivos territórios, a \\ fim de promover o aumento da \\ produção e do nível de emprego e \\ renda dentro da unidade (Ferreira \\ et al., 2005). \\ ${ }^{2}$ Para este momento, vale tratar o \\ individualismo metodológico com \\ base na síntese feita por Paulani \\ (1996, p. 107): "O individualismo \\ metodológico é um preceito \\ metateórico atinente ao mundo \\ dos fatos sociais, segundo o qual a \\ explicação de um fenômeno social \\ qualquer só pode ser considerada
}


científica se, por intermédio dela, pudermos reduzir tal fenômeno às ações intencionais (particularmente ao grupo de consideradas racionais) dos indivíduos e à forma como elas interagem".

${ }^{3}$ Em sucinta delimitação acerca das características da síntese neoclássica, Affonso (2003, p. 12) destaca "a descentralização da moeda enquanto reserva de valor e indicador da incerteza quanto ao futuro, a reintrodução do paradigma do equilíbrio, a metamorfose do conceito de 'incerteza' em 'risco' (sujeito ao cálculo probabilístico), a derivação do desemprego a partir das supostas 'imperfeições' no mercado de trabalho ('inflexibilidade' dos salários à queda, 'legislação trabalhista'), etc.”.

${ }^{4}$ A noção de otimização do bem-estar econômico restou consolidada a partir do conhecido "Ótimo de Pareto", conceito fundado na ideia de que uma solução ótima estaria naquela em que uma política consegue maximizar os ganhos para todos os indivíduos envolvidos com uma dada utilidade, até o limite em que nenhum agente consiga maximizar o seu bemestar sem produzir prejuízo a outro (Caliendo, 2008). Sobre as limitações inerentes ao aparato analítico da eficiência paretiana, ver Possas (2004, p. 75-79).

${ }^{5} \mathrm{O}$ questionamento da ação descentralizada do Estado, por parte de Arrow (1963), fez-se por meio da denúncia de impossibilidade de qualquer mecanismo atender, ao mesmo tempo, os critérios de:

a) racionalidade coletiva,

b) não restrição a preferências individuais, c) princípio de Pareto, d) independência das alternativas irrelevantes, $\mathrm{e}$ e) ausência de ditaduras.

${ }^{6}$ Segundo Affonso (2003), o principal autor a levantar esse questionamento foi Samuelson (1954).

${ }^{7}$ Por essa razão, Kenyon (1997) ressalta a ideia de que a instituição de impostos locais seria uma das maneiras de garantir melhor proporção entre a carga tributária e os benefícios concedidos aos habitantes dos territórios.

${ }^{8}$ Robert Lucas funda sua crítica à política monetária no pressuposto das "expectativas racionais", arguindo que as empresas erram porque o futuro é incerto, mas sempre tentam se portar de modo mais eficiente. Dessa forma, a política monetária seria ineficaz, pois os agentes sempre se antecipam a ela.

${ }^{9} \mathrm{O}$ autor se utiliza do individualismo metodológico hayekiano, tomando os fenômenos sociais como derivações das ações individuais e, nesse caso, abstraindo as entidades (agentes) como pessoas, Estados e nações.

${ }^{10}$ Vale registrar que, no curso das mutações internas ocorridas no mainstream ao longo dos anos, Oates virá a ponderar alguns dos seus posicionamentos, considerando as "falhas" resultantes da desordenada concessão de incentivos fiscais pelos entes subnacionais. Passará, então, a evidenciar com mais veemência a perversidade e a ineficiência de tal falta de regulamentação.

${ }^{11}$ Vale mencionar que Oates \& Schwab (1988) admitem serem os benefícios, ou pontos negativos envolvidos, insuficientes para aproximar o contexto de competição entre jurisdições ao de uma vantagem competitiva de mercado, até pela própria limitação do número de governos subnacionais (Kenyon, 1997). Como algumas das principais limitações às formulações de Oates, a bibliografia pertinente menciona o fato de que, numa economia caracterizada por um contexto de incertezas, as empresas, muito possivelmente, detêm mais informações sobre os prováveis impactos dos benefícios do que o próprio governo (Kenyon, 1997).

${ }^{12}$ Pondera-se, aqui, a possibilidade de um bem público ser oferecido de forma mais eficiente pelo poder central, graças ao ganho de escala constante nessa prestação (Schnellenbach, 2005).

${ }^{13}$ Com base na teoria dos jogos, McGuire (1991) aponta como a "primeira melhor" situação aquela configurada quando algum Estado, em particular, oferece isenção e não tem essa isenção igualada ao outro Estado competidor; a segunda melhor situação e, ao mesmo tempo, a estratégia que mais maximiza o bem-estar, de maneira geral, configura-se quando nenhum dos Estados oferece incentivo fiscal; o terceiro melhor cenário, por sua vez, é aquele em que ambos os Estados oferecem incentivos; e o pior cenário seria a situação em que o Estado não oferece o incentivo, mas o seu concorrente (outro Estado) o faz.

${ }^{14}$ Quanto à possibilidade de um agente externo para coordenar o acordo não competitivo, McGuire (1991) indaga, sugestivamente, se seria, ou não, o governo federal o incumbido de assumir tal papel.

${ }^{15}$ Ao mencionar os trabalhos empíricos denunciadores dos efeitos negativos, ou mistos, da descentralização competitiva, sobre a condição fiscal de um país ou sua inflação, Volden (2004) elenca: Jonathan Rodden, "The Dilemma of Fiscal Federalism: Grants and Fiscal Performance Around the World," American Journal of Political Science 46 (July 2002): 670-687; Daniel Treisman, "Decentralization and Inflation: Commitment, Collective Action, or Continuity?" American Political Science Review 94 (December 2000): 837-857; Erik Wibbels, "Federalism and the Politics of Macroeconomic Policy and Performance," American Journal of Political Science 44 (October 2000): 
687-702. For evidence of the link between federalism and fiscal decentralization see Maria Escobar-Lemmon, "Fiscal Decentralization and Federalism in Latin America," Publics: The Journal of Federalism 31

(Fall 2001): 23-41.

${ }^{16}$ Segundo Blankart (2002), o problema abraçado pela $\mathrm{Public}$ Choice não é a proteção dos governos quanto à competição excessiva, mas, sim, a promoção da eficiência alocativa, por meio da regulação da concorrência entre governos.

${ }^{17} \mathrm{O}$ sugerido monitoramento das ações públicas poderia ser feito, então, tanto por cidadãos como por instituições formais, incumbidas de tal propósito (The World Bank, 1997)

${ }^{18}$ Propõe-se, nesse sentido, uma redução da discricionariedade, até então muito presente na ação das autoridades públicas (The World Bank, 1997)

${ }^{19}$ Em referência, especificamente, ao caso brasileiro, o relatório menciona as dificuldades enfrentadas pelo país, ao final da década de 1980, para gerir um processo coordenado de descentralização, em plena instauração da transição democrática. Diante disso, confirma três das recomendações institucionais feitas, genericamente, aos países em desenvolvimento, quais sejam: a descentralização das receitas deve corresponder à descentralização dos gastos; 0 governo central deve manter forte restrição orçamentária sobre os entes subnacionais; e a estruturação das normas constitucionais, principalmente as eleitorais, deve estar composta de modo a garantir a implementação das duas primeiras medidas. Sugeriu-se, então, entre outros, a estipulação de uma restrição constitucional consubstanciada na limitação da capacidade da União de conceder novos empréstimos a Estados endividados - nesse caso, trata-se de "estados" como entes subnacionais. Assim, acompanhando as denominações utilizadas nas finanças públicas, as quais distinguem o "estado subnacional" do "Estado nacional", proponho manter com letra minúscula (The World Bank, 2000).

${ }^{20}$ A esse respeito, o dito relatório menciona a delegação de competência como fator tendente a afetar a estabilidade política, repercutindo, por conseguinte, no fornecimento de bens e serviços públicos e na estabilidade macroeconômica, de modo geral.

${ }^{21}$ Com a vitória do capitalismo, nos anos 1980 e 1990 - tanto no âmbito geopolítico como ideológico -, grande parte dos problemas do mainstream passou a ser considerada endógena, não sendo mais crucial, portanto, a demonstração formal de uma eficiência ótima. Flexibilizamse, então, alguns supostos axiomáticos da teoria hegemônica, derrubando-se as hipóteses de mercado perfeito e de informação simétrica (Affonso, 2003).

${ }^{22}$ Inicialmente proposto por Kornai (1986), esse modelo de disciplina fiscal foi apresentado em cotejo com o Soft Burget Constraint (SBC), o qual, em oposição à $\mathrm{HBC}$, se caracterizava por prever uma restrição orçamentária mais suave.

${ }^{23}$ Ao exemplificar trabalhos que utilizam a "teoria dos jogos" para a elucidação dos fenômenos federativos, nesse âmbito, Oates (2005) cita: Goodspeed (2002);

Rodden, Eskeland e Litvack (2003); e Inman (2003).

${ }^{24}$ A noção de totalidade concreta não consiste num "método que pretenda ingenuamente conhecer todos os aspectos da realidade", mas, sim, trata-se de uma "orientação heurística”, ou seja, um postulado de investigação capaz de subsidiar o "estudo, descrição, compreensão, ilustração e avaliação de certas seções tematizadas da realidade" (Kosik, 1976, p. 35-36). Essa perspectiva, em vez de de se valer de esquemas analíticos a priori, concebe o "real" como uma totalidade de relações e determinações diversas, as quais só podem ser efetivamente conhecidas mediante a identificação das suas contradições materiais objetivas. Dessa forma, busca apreender os fenômenos estudados com base em suas particularidades histórico-sociais, concebendo seus determinantes não pela idealização abstrata da figura de um indivíduo maximizador, mas pela materialidade concreta do contexto estudado, cujas transformações são engendradas por contradições em processo, e não por agentes planificados em busca dos seus respectivos autointeresses.

${ }^{25}$ Embora exista uma série de derivações acerca do que se entende por individualismo metodológico, vale trazer a concepção de um dos seus principais expoentes, Elster (1989), caracterizada pela crença de que todos os fenômenos sociais seriam explicáveis, em princípio, apenas com base em elementos como pessoas e suas ações interessadas.

${ }^{26}$ Ainda que não se possa limitar o individualismo metodológico

à escola neoclássica, esta concentrou uma das suas expressões mais fortes, presente, desse modo, na compreensão do fenômeno federativo pelo mainstream.

${ }^{27}$ Nesse sentido, o individualismo metodológico passa a questionar os fundamentos e, por assim dizer, permear os campos da ciência política, da sociologia, da antropologia e da psicologia social.

${ }^{28}$ Em alusão às diferentes dimensões, o autor menciona as econômica, social, política, étnica, religiosa, etc.

${ }^{29}$ A esse respeito, podem ser mencionados os processos de internacionalização do capital e da divisão internacional do trabalho. 
${ }^{30}$ Em tentativa de classificação, Nicolas (1998) esboça quatro matrizes espaço-temporais básicas: a) a "circular", característica das sociedades tradicionais, em que a permanência e a repetição se constituem pela apropriação quase que imutável do espaço; b) a "linear", mais próxima de uma visão desenvolvimentista, na qual se intenta um avanço no controle do espaço e do tempo; c) a "fordista", marcada por uma racionalidade baseada no trabalho divisível em porções temporais dissociadas e, ao mesmo tempo, linearmente articuladas no espaço e; a "pós-fordista", identificada pela "simultaneidade no espaço", a qual possibilita a transformação do processo de internacionalização em mundialização, mediante a sucessão no espaço e no tempo dos processos organizativos.

${ }^{31} \mathrm{O}$ "tempo de rotação" de um capital, segundo explica Harvey (2007), consiste na soma do tempo de produção com o tempo de circulação, de modo que, quanto maior o tempo de circulação, menor a realização do plusvalor, na medida em que o capital imobilizado não gera excedentes nesse período.

${ }^{32} \mathrm{O}$ processo de "aniquilação do espaço pelo tempo" pode ser, brevemente, descrito como a organização espacial racional das atividades produtivas, como forma de superar as limitações físicas do espaço, reduzindo o tempo de rotação socialmente necessário entre a produção e o consumo. Esse processo vem sendo cada vez mais aprofundado em face do desenvolvimento de novas tecnologias e estratégias organizativas (Harvey, 2007). 
ABRUCIO, F. L.; COSTA, V. M. F. Reforma do Estado e o contexto federativo brasileiro. São Paulo: Konrad-Adenauer-Stiftung, 1999.

ACIR, U. S. Advisory

Commission on

Intergovernmental Relations. Interjurisdictional Tax and Policy Competition: Good or Bad for the Federal System? Washington, (April), 1991.

AFFONSO, R. B. A. O Federalismo e as teorias hegemônicas da Economia do Setor Público na segunda metade do século XX: um balanço crítico. 2003. $268 \mathrm{f}$.

Tese (Doutorado em Economia), Instituto de Economia da Unicamp, Campinas, 2003.

AFFONSO, R. B. Á.; SILVA, P. L. B. (Orgs.). A Federação em perspectiva: Ensaios selecionados. São Paulo: Fundap (Série Federalismo no Brasil), 1995.

ARROW, K. J. Social choice and individual values. New York: John Wiley, 1963.

BLANKART, C. B. A public choice view of tax competition. Public Finance Review, v. 30 , n. 5, p. 366-376, 2002.
BONEFELD, W. Globalization and state: A note on Joachim Hirsch. Studies in Political Economy, n. 58, Spring 1999.

BRANDÃO, C. A. A dimensão espacial do subdesenvolvimento: Uma agenda para os estudos urbanos e regionais. Campinas, 2004. Tese (Livre Docência em Economia) - Universidade Estadual de Campinas, Campinas, 2004.

BUCHANAN, J.; TULLOCK, G. El cálculo del consenso fundamentos lógicos de la democracia constitucional. Barcelona: Planeta-Agostini, 1993. BUCHANAN, J. M. Federalism as an ideal political order and an objective for constitutional reform. Publius: The Journal of Federalism, v. 25, n. 2, p. 1-9, 1995.

BUCHANAN, J. M. Federalism and individual sovereignty. Cato Journal, v. 15, n. 2-3, p. 259-68, 1995, 1996.

CALIENDO, P. Direito Tributário e Análise Econômica do Direito. Rio de Janeiro: Elsevier, 2008.

DYE, T. R. American federalism: Competition among governments. Massachusetts/ Toronto: Lexington Books, 1990.
ELSTER, J. Marx hoje. São Paulo: Paz e Terra, 1989.

FERREIRA, S. G.; VARSANO, R.; AFONSO, J. R. Interjurisdictional fiscal competition: A review of the literature and policy recommendations. Revista de Economia Política, São Paulo, v. 25, n. 3, 2005.

FILIPPOV, Mikhail. Riker and Federalism. Constitutional Political Economy, v. 16, p. 93-111, 2005.

FIORI. J. L. O federalismo diante do desafio da globalização. In: AFFONSO, R. B. A.; SILVA, P. L. (Orgs.). A Federação em perspectiva. São Paulo: Fundap, 1995.

GOODSPEED, T. J. Tax competition, benefit taxes and fiscal federalism. National Tax Journal, v. 51, n. 3, p. 579-586, 1998.

GOODSPEED, Timothy

J. Bailouts in a Federation. International Tax and Public Finance, v. 9, p. 409-421, 2002.

HARMES, A. The Political Economy of Open Federalism. Canadian Journal of Political Science, v. 40, n. 2, p. 417-437, 2007.

HARRIS, J.; HUNTER, J.; LEWIS, M. C. (Eds.). The new institucional economics and the third world development. London: Routledge, 1995.
HARVEY, D. Espacios del capital: Hacia una geografía crítica. Madrid: Akal, 2007.

HARVEY, D. La condición de la posmodernidad. Investigación sobre los orígenes del cambio cultural. Buenos Aires: Amorrortu Editores, 2004. HIRSCH, J.; KANNANKULAM, J. The spaces of capital: The political form of capitalism and the internationalization of the State. Antipode, v. 43, p. 12-37, 2010.

HIRSCH, J. Globalización, capital y Estado. México DF: UAM$\mathrm{X}, \mathrm{CSH}$, Depto. De Relaciones Sociales, 1996.

INMAN, R. P. Transfers and bailouts: Enforcing local fiscal discipline with lessons from U.S. Federalism. In: RODDEN, J. et al. (Eds.). Fiscal Decentralization and the Challenge of Hard Budget Constraints. Cambridge, MA: MIT Press, p. 35-83, 2003.

JESSOP, B. The changing governance of Welfare: Recent trends in its primary functions, scale, and modes of coordination. Social Policy or Administration, v. 33, n. 4 , p. 348-359, 1999 . 
JESSOP, B. The crisis of the national spatio-temporal fix and the tendential ecological dominance of globalizing capitalism. International Journal of Urban and Regional Research, v. 24, n. 2, 2000 a.

JESSOP, B. The State and the contradictions of the knowledge-driven economy. In: BRYSON, J. R.; DANIELS, P. W.; HENRY, N. D.; POLLARD, J. (Eds.). Knowledge, Space, Economy, London: Routledge, $2000 \mathrm{~b}$

JESSOP, B. El futuro del Estado capitalista. Madrid: Los Libros de La Catarata, 2008.

JESSOP, B. O Estado, o poder, o socialismo de Poulantzas como um clássico moderno. Rev.

Sociol. Polít., Curitiba, v. 17, n. 33, p. 131-144, 2009.

KENYON, D. A. Theories of interjurisdictional competition. New England Economic Review, p. 14-35, 03-04, 1997.

KORNAI, J. The soft budget constraint. Kyklos, Zürich, v. 39, n. 1, p. 3-30, 1986.

KOSIK, K. Dialética do concreto. 2. ed. Rio de Janeiro: Paz e Terra, 1976.

LENGYEL, E. Globalización, capital y Estado. (Resenha). Política y Cultura, p. 373-378, 1997.

LYNCH, G. P. Protecting individual rights through a federal system: James Buchanan's view of Federalism. Publius: The Journal of Federalism, v. 34, n. 4, p.153-168, 2004.
MCGUIRE, T. Federal aid to States and localities and the appropriate competitive framework. In: KENYON, D.; KINCAID, J. Competition Among States and Local Governments. Washington, D. C.: The Urban Institute Press, 1991.

NICOLAS, D. H. Tempo, espaço e apropriação social do território: Rumo à fragmentação na mundialização. In: SANTOS, M.; SOUZA, M. A. A.; SILVEIRA, M. L. (Orgs.). Território, Globalização e Fragmentação. São Paulo: Hucitec, 1998.

OATES, Wallace E. Toward a Second-Generation Theory of Fiscal Federalism. International Tax and Public Finance, v. 12, p. 349-374, 2005.

OATES, Wallace E. An economic approach to federalism. In: BAKER, S.; ELLIOTT, C. (Orgs.). Readings in public sector economics, [s.1.], D. C. Heath and Company, p. 559-565, 1990.

OATES, W. E.; SCHWAB, R. M.

Economic competition among jurisdictions: Efficiencyenhancing or distortioninducing? Journal of Public Economics, v. 35, p. 333-354, 1988.

OFFE, Claus. Contradiciones del Estado del bienestar. Madrid: Alianza Editorial, S. A., 1990

OFFE, Claus. Structural problems of the Capitalist State: Class rule and the political system. On the selevtiveness of political institutions. Von Beyme (Ed.). German Politcal Studies, v. 1, 1974, p. 31-54.
OLIVEIRA. F. Teorias da

Federação e do Federalismo Fiscal: O caso brasileiro. Escola de Governo da Fundação João Pinheiro. Texto para discussão: Minas Gerais, 2007.

PAULANI, L. M. Hayek e o individualismo metodológico no discurso econômico. $\mathrm{Lua}$ Nova, n. 38-96, p. 97-124, 1996.

POSSAS, M. L. Eficiência seletiva: Uma perspectiva neoschumpeteriana evolucionária sobre questões econômicas normativas. Revista de Economia Política, v. 24, n. 1 , p. 93, jan./mar. 2004.

POULANTZAS, N. Estado, poder y socialismo. 2. ed. Madrid: Siglo XXI de España Editores S. A., 1980.

PRZEWORSKI, A.; WALLERSTEIN, M. O capitalismo democrático na encruzilhada. Novos Estudos Cebrap, São Paulo, Cebrap,

n. 22, p. $29-44,1988$.

\section{PRZEWORSKI, A. Marxismo e} escolha racional. 1988.

RIKER, W. H. Federalism: Origin, operation, significance. Boston: Little Brown and Company, 1964.

RODDEN, J.; ESKELAND, G. S.; LITVACK, J. Fiscal decentralization and the challenge of the hard budget constraint. Cambridge: MIT Press, 2003.

SAMUELSON, P. A. The pure theory of public expenditure. Review of Economics and Statistics, p. 36, 1954.
SANTOS. Milton. Por uma outra globalização: Do pensamento único à consciência universal. Rio de Janeiro: Record, 2001.

SARAIVA, J. F. S. A busca de um novo paradigma: Política exterior, comércio externo e federalismo no Brasil.

Revista Brasileira de Política Internacional, v. 47, n. 2, p. 131-162, 2004.

SCHNELLENBACH, J. The Dahrendorf hypothesis and its implications for (the theory of) economic policy-making. Cambridge Journal of Economics, v. 29, p. 997-1009, 2005.

SORENS, J. The Institutions of Fiscal Federalism. Publius: The Journal of Federalism, v. 41, n. 2, p. 207-231, 2010.

THE WORLD BANK. World development report 1997 The state in a changing world. New York, Oxford University Press, 1997.

THE WORLD BANK.

World development report $1999 / 2000$ - Entering the $21^{\text {st }}$ century. New York, Oxford University Press, 2000.

THÉRET, B. Del principio federal a una topología de las federaciones: Algunas propuestas. Foro Internacional, XLVI (1), p. 29-65, 2004.

THÉRET, B. Du federalisme et de la protection sociale em Amerique et em particulier au Canada. In: Rapport pour La convention d'étude. Commissariat Géneral du Plan, n. 5,4 juil. 1995 . 
VARSANO, R. B. A guerra fiscal do ICMS: Quem ganha e quem perde. Planejamento e Políticas Públicas, Brasília: IPEA, n. 15, p. 3-18, jun. 1997.

VARGAS, N. C. Estados no Brasil e o controle fiscal e financeiro pela União no pósreal. 2006. 293 f.. Tese (Doutorado em Economia Aplicada) -

Faculdade de ??, Universidade Estadual de Campinas,

Campinas, 2006.

VOLDEN, C. Origin, operation, and significance: The Federalism of William H. Riker. Publius:

The Journal of Federalism, v. 34,

n. 4, p. 89-108, 2004.

E-mail de contato dos autores: renatoluispm@gmail.com

hcairoca@cps.ucm.es

WILSON, John D. Theories of

Tax Competition. National Tax

rosadelafuente@gmail.com

Journal, v. 52, p. 269-304, 1999.

Artigo recebido em dezembro de 2012 e aprovado em junho de 2013 
